Original scientific paper

UDK: 355.02:341.3(327(497))

DOI: $10.5937 /$ jrs $15-24025$

Received: 15 November 2019 / Accepted: 16 March 2020

\title{
Criminalization as Anxious and Ineffective Response to Foreign Fighters Phenomenon in the Western Balkans
}

\author{
LUKA GLUŠAC* \\ Institute for Philosophy and Social Theory, University of Belgrade, Serbia
}

\begin{abstract}
Despite not being a new phenomenon, nor an Islamic specificum, only recently when the West has increasingly become a potential target of returning foreign fighters from the Syrian theater has the international community reacted. The UN Security Council called on Member-states to, inter alia, immediately amend their national legislation to criminalize travelling abroad for terrorist purposes. However, as I identify in this article, contrary to majority of the Western countries, the Western Balkan countries opted to amend their legislation to criminalize travelling abroad to join conflict irrespective of its connection with terrorism, going well beyond the intended aim of the Security Council's resolutions. I argue that this broader criminal law approach is difficult to justify from either preventive or reactive perspectives. It is, in fact, an anxious and ineffective response to foreign fighters phenomenon. It is anxious because existing data shows that countries from the region have suffered fewer extremist attacks than the West. Notwithstanding, they still decided to introduce far more aggressive legislative changes, even though it only amplified securitizing moves performed by fighters' recruiters. I further demonstrate that the implementation of this new legislation has been ineffective particularly due to: (1) the challenge of securing court-strong evidence, especially those gathered through international intelligence cooperation; (2) its application mainly as an alternative when other terrorism-related offences cannot be proved; and (3) biased law application in countries that have returning fighters from both Middle East and Ukraine.
\end{abstract}

Keywords: foreign fighters, criminalization, Western Balkans, intelligence, extremism, securitization

\section{Introduction}

At the very outset, it should be mentioned that foreign fighters are a phenomenon that is neither new nor an Islamic specificum. Foreign fighters have participated in armed conflicts throughout modern history. ${ }^{1}$ Historical cases include the Greek War of Independence during the 1820s, the civil war in Mexico during the 1830s, and the Texas Revolution in the 1840s. The Spanish Civil War and the Israeli War of Independence in the first

1 See more on foreign fighters from historical perspective in Arielli 2018.

*luka.glusac@instifdt.bg.ac.rs and lukaglusac@gmail.com. 
post-World War II years also witnessed an important number of foreign fighters. ${ }^{2}$ Contemporary cases include the war in Afghanistan in the 1980s, the conflicts in Chechnya and Iraq, to the current conflicts in the Middle East and Ukraine. The Spanish Civil War, the Arab-Israeli wars and the war in Afghanistan are the most scrutinized historical examples of significant involvement of foreign fighters. ${ }^{3}$

Historically, the West had both imported foreign fighters, as in Greece, Spain, or former Yugoslavia, and exported them, such as in cases of Israel or Afghanistan. It had also received returning fighters from conflicts worldwide but had not perceived them as a national security threat. That has changed in the post $9 / 11$ period, especially after terrorist attacks on Western European soil and the burst of the Syrian conflict. Understanding that returning foreign fighters from the Syrian theater may return to Europe equipped with skills and motivation to conduct violent operations caused the West to provide more structured international institutional response. Western efforts to tackle this issue have been shaped through the United Nations (UN), and regional organizations, including the Organization for Security and Co-operation in Europe (OSCE) and the European Union (EU). The West has been particularly anxious about potential terrorist activities of returning foreign fighters. These efforts were mainly focused on requests to the Member States to immediately amend their national legislation to criminalize participation in conflicts abroad. At the same time, international organizations, particularly the UN, have decided to concentrate on foreign terrorist fighters (FTFs), as a narrower category.

In this article, I demonstrate that while in most European countries individuals who return from a conflict zone can be charged only if certain specific terrorism-relevant behavior is demonstrated, in the Western Balkans travelling abroad to join the conflict was criminalized irrespective of its relations to terrorism or other major crimes. I identify and analyze this new legislation in the Western Balkans countries, arguing that this broader scope of criminalization of foreign fighters in the Western Balkans is indeed curious, given the fact that their overall number is not high, either in absolute or relative to general population in the region. It is believed that some 1,000 individuals (men, women, children, and elderly) from the Western Balkans traveled to Syria and Iraq. No more than 300 in total have returned. ${ }^{4}$ Furthermore, Western countries have been much more exposed to radical violent extremism in the last twenty years or so than the Western Balkans, and yet they decided to criminalize only travelling abroad for the purpose of terrorism. In addition, the Western Balkans are interesting for studying the foreign fighters phenomenon, because in the past, the region was a destination for foreign fighters; recently, it has exported them to distant war theaters.

My aim is to show that with introducing this broader scope of criminalization, the Western Balkan countries have exhibited unusual anxiety about (returning) foreign fighters, which can hardly be objectively justified. I concentrate on the implementation of new legislation from both preventive and reactive purposes to test my hypothesis that such criminalization of foreign fighters is an ineffective and, to a certain degree, counterproductive strategy. From a preventive perspective, I argue that a threat of criminal pros- 
ecution only strengthens potential recruits' sense that their transnational identity group needs a defensive mobilization to tackle an existential threat. Looking at it from a reactive (repressive) angle, I argue that securing court-strong evidence for criminal prosecution of foreign fighters upon their return to home countries is extremely challenging, particularly given that information received through international intelligence cooperation can almost never be used in court proceedings. Consequently, countries focus on those criminal offences committed on their own soil, which allow them the usage of a rich selection of special investigative measures and techniques. In other words, I argue that if foreign fighters do not incriminate themselves through social media or get caught in flagrante on the battlefield and are arrested on-site, chances are that they would avoid criminal prosecution. Finally, as a subsidiary goal, I am also interested in determining the Western Balkan countries' treatment of fighters who participated in the Syrian and Ukrainian conflicts, depending on the theater they come back from.

Media and policy reports have substantively covered the issue of foreign fighters from the Western Balkans; ${ }^{5}$ however, they have usually dealt with their number and/or distribution within the region. Some coverage included personal testimonies ${ }^{6}$, and most recently results of court proceedings ${ }^{7}$. Literature concerning foreign fighters with a focus on the Western Balkan region is notably scarce. ${ }^{8}$ Existing literature missed the opportunity to analyze comparatively new legislation and to put these developments in a wider perspective, especially taking into account a different scope of new legislation on the Western Balkans compared to the rest of Europe. With this article, I aim to contribute to this research and policy analysis gap and to shed more light on this particular region.

This article starts by defining foreign fighters and returning foreign fighters. I then present how those returning foreign fighters have alarmed the Western countries, which responded to this perceived security challenge by adopting three resolutions of the UN Security Council, aiming at those returning fighters who pose a terrorist threat. Further, I concentrate on the Western Balkans to demonstrate that their legislative activity went well beyond the implementation of the Security Council resolutions, i.e. they criminalized participation in conflicts abroad irrespective of its connection with terrorism. Following that, I use the case-law of the Western Balkan countries to show that such broad criminalization is an ineffective strategy. I conclude with a summary of the results and their further implications.

\section{Defining Foreign Fighters}

According to Thomas Hegghammer, foreign fighters constitute an intermediate (indirect) actor category lost between local rebels on one hand, and international terrorists on the other. ${ }^{9}$ This is why researchers are using different terminologies for them, e.g. transna-

9 Hegghammer 2010, 55. 
tional insurgents, foreign combatants, global fighters, etc, depending on their specific research angles and designs.

Notions of foreign fighters are shaped by a state-centric perspective. When we speak about "foreign", we refer to nationality: A volunteer is foreign if he holds the citizenship of a country external to a conflict. ${ }^{10}$ Barak Mendelsohn correctly notes that this ontology often fails to correspond to the foreign fighter's sense of identity. Moreover, we tend to treat "foreign" and "non-foreign" (domestic) fighters as a dichotomy, ignoring the different levels of "foreignness". In some places, simply traveling to the next village makes one a foreigner. Different identity markers - province of origin, ethnic group, tribe, sub-clan or any other - can determine one's level of "foreignness". ${ }^{11}$ Nevertheless, "citizenship remains a major attribute for differentiating domestic from foreign fighters, both in academia and in the discourse of international community". ${ }^{12}$

In one of the most cited definitions, David Malet describes foreign fighters as "non-citizens of conflict states who join insurgencies during civil conflict" ${ }^{13}$ Building on this formulation, Thomas Hegghammer defines a foreign fighter as an agent who: (1) has joined and operates within the confines of an insurgency; (2) lacks citizenship of the conflict state or kinship links to its warring factions; (3) lacks affiliation to an official military organization; and (4) is unpaid. ${ }^{14}$ This Hegghammer's definition is important because it sets foreign fighters apart from other types of violent actors who cross borders. Criterion (4) excludes mercenaries, who are paid and follow the highest bidder. Criterion (3) excludes soldiers, who are usually salaried and go where their generals send them. Criterion (2) excludes returning diaspora members or exiled rebels, who have a preexisting stake in the conflict. Such a distinction disappears in Idean Salehyan's term "transnational insurgent"15 or John Mackinlay's "global insurgent"16. This is relevant because ethnic or kinship links to insurgents facilitate mobilization considerably. ${ }^{17}$ Finally, criterion (1) distinguishes foreign fighters from international terrorists, who specialize in out-of-area violence against noncombatants. This distinction is rarely made; most works on militant Islamism use generic terms such as "jihadists" or "Salafi jihadists" to describe any transnational violent Islamist, whether some undertake suicide bombings in a Western capital or mortar attacks in a war zone. ${ }^{18}$ In reality, most foreign fighters never engaged in out-of-area operations,

10 Glušac 2015, 36.

11 Mendelsohn 2011, 192.

12 Glušac 2015, 36.

13 Malet 2008, 9.

14 Hegghammer 2010, 57-8.

15 Salehyan 2009.

16 Mackinlay 2002.

17 Hegghammer 2010, 58.

18 See more in: Glušac 2015, 37. 
but in one combat area at the time. ${ }^{19}$ In this article, I adopt Hegghammer's definition, with one note. I will consider a foreign fighter also a person who fulfills the first three criteria, but is paid, as long as financial reasons are not the main reason why that person joined the conflict, contrary to mercenaries. I am introducing this difference because existing research has shown that some foreign fighters have been paid for their participation in conflict. However, according to their testimonies while economic interests were usually a factor, they were not a decisive reason for their involvement. ${ }^{20}$

\section{Returning Foreign Fighters}

The foreign fighters phenomenon is about more than their contribution on their first battlefield. As emphasized by Mendelsohn, it encompasses a life cycle that starts when an individual begins to consider joining a fight in a country that is not theirs, continues through their involvement in the conflict, and ends with their actions once they leave that arena. ${ }^{21}$ Stephanie Kaplan notes that the "foreign fighter problem is actually several problems" that need to be disaggregated for the sake of better understanding and development of effective policies. She suggests that the life cycle of foreign warriors be divided into three phases: the pre-war mobilization phase, the war phase, and the post-war phase..$^{22}$

The current worries about foreign fighters seem to center around the threat of „bleed out “. ${ }^{23}$ Namely, jihadi veterans, equipped with new knowledge of tactics, training, recruitment, media, and technical skills (in building bombs, for instance) may take their skills elsewhere. ${ }^{24}$ They may facilitate the initiation or escalation of terrorism in their home country or in other arenas, and enhance the power of insurgencies and terrorist groups. ${ }^{25}$

The key question is what happens to these fighters when they leave the conflict, particularly how the earlier phases shape their future trajectory. While many foreign fighters return home and reintegrate into society, some do not. Their experience is often a constitutive event that shapes who they are and what they do. Many find it hard to return to daily lives. They seek the company of people like them, and in many places their reputation in their community is tied to their identity as fighters. ${ }^{26}$

In some cases, Mendelsohn notes, even when a former fighter tries to leave his past behind, his state continues to identify him as a threat, thus pushing him back to the under-

19 Hegghammer 2010, 58.

20 Kursani 2018; Xharra and Gojani 2017.

21 Mendelsohn 2011, 190.

22 Helfont 2011, 3.

23 Glušac 2015, 38.

24 Mendelsohn 2011, 199.

25 Ibid.

26 Glušac 2015, 39. 
ground life and into the arms of comrades who face the same problem. ${ }^{27}$ Some of these individuals go on to form the infrastructure for the next generation of foreign fighters. ${ }^{28}$

Returning foreign fighters exhibit unpredictability in their behavior as they are likely to suffer from posttraumatic stress disorder (PTSD) and emotional instability. ${ }^{29}$ As such, they could indirectly and directly partake in lone wolf attacks, act as "virtual planners" who engage in logistical or financial duties and share operational and technical knowledge with others. ${ }^{30}$ They could also become leaders who groom remote sympathizers into potential attackers ${ }^{31}$ or facilitators for new foreign fighters.

Available information suggests that foreign fighters who travelled to and actively engaged with the so-called "Islamic State" in Iraq and the Levant (ISIL), Al-Qaida and associated groups in Iraq, Syria and other countries - such as Afghanistan, Yemen, Libya, Pakistan and Somalia - came from an estimated 110 states around the globe. ${ }^{32}$ While estimates are by their very nature unreliable, linked in part to definitional problems, it has been suggested that more than 40,000 foreign terrorist fighters had travelled to just Iraq and Syria alone. $^{33}$

Regarding the return or "reverse flow" of foreign fighters, which has taken place in waves, reliable statistics are rather elusive. One report tracked 5,600 fighters who had returned to their home countries globally by $2015 .{ }^{34}$ Another report, focused on the foreign fighters issue in the EU, suggested that some 30 per cent of them had returned or moved to other states by 2016. ${ }^{35}$ The "shrinking territories" in Syria and the collapse of the socalled "Islamic State" caliphate in Iraq in October 2017 contributed to the latest wave of returnees. ${ }^{36}$ By early 2018, evidence pointed to both a sharp decrease in the number of those travelling to Iraq and Syria and to growing concern regarding the impact of foreign fighters returning to their home states or moving on to other - sometimes unknown locations. ${ }^{37}$ Hegghammer argues that the involvement of returning foreign fighters in a terrorist cell increases the likelihood of planning and the execution of a successful attack with a higher number of fatalities. Likewise, he found that no more than $11 \%$ of fight-

\footnotetext{
27 Mendelsohn 2011, 199.

28 Ibid.

29 See ODIHR 2018, 9-10.

30 Europol 2016.

31 Moreng 2016.

32 ODIHR 2018, 10.

33 United Nations 2017.

34 Soufan Group 2015.

35 van Ginkel and Entenmann 2016, note 16.

36 UNCTED 2018.

37 Many FTFs remain unaccounted for, having either died overseas or moved to unknown locations. See, for example, Washington Post 2018. 
ers would pose a threat upon returning home. ${ }^{38}$ Although Gardner argued that an attack by a returning foreign fighter would be inevitable, ${ }^{39}$ a study done by Hegghammer and Nesser in 2015 concluded that only 1 in 200 to 300 returnees became involved in plots or attacks. ${ }^{40}$ Conversely, Cragin discovered that even a small number of returnees could undermine peace and security. ${ }^{41}$ Although there are variations in the perceived level of threat returning foreign fighters pose, there is a general consensus that by "upholding or performing secondary functions of the extremist networks", the returnees pose a serious and continuous threat to societies. ${ }^{42}$ In light of these dynamics, concerns that ISIL is turning its sights elsewhere, potentially using returning foreign fighters, have been a salient feature of the political discourse and related developments in law and policy. ${ }^{43}$

\section{Criminalization: International and National Responses}

As indicated, exactly those returning foreign (terrorist) fighters have sparked keen interest among Western communities. Once the West became a potential target of returning foreign fighters from the Syrian theater (who fought for ISIL), the international community responded. The UN Security Council adopted three resolutions-Resolution 2170, 2178 and 2396 - calling member states to, inter alia, immediately amend their national legislation to criminalize participation in conflicts abroad.

Resolutions were adopted under Chapter VII of the Charter, seeking to strengthen international cooperation, update the national legislations and create a common approach to countering this growing threat. Resolution 2170 (2014), aimed primarily at suppressing ISIL's actions, was the first to recognize the importance of foreign fighters. The Security Council demanded that all foreign terrorist fighters withdrew from the war zones and condemned their recruitment that contributed to violent radicalization and the spread of conflict. It also urged the Member States to intensify efforts to prevent at the national level, through various legal and practical measures, the recruitment and deployment to the battlefields in the Middle East.

In late September 2014, the Security Council adopted Resolution 2178. Thus far, it is the most comprehensive resolution dealing with the problem of foreign fighters. It asks UN member states to prevent and suppress the recruiting, organizing, transporting or equipping of individuals who travel to a state other than their states of residence or nationality to perpetrate, plan, prepare, or participate in terrorist acts, as well as to provide or receive terrorist training, and to finance their travel and their activities.

\footnotetext{
38 Hegghammer 2013.

39 Gardner 2013.

40 Hegghammer and Nesser 2015.

41 Cragin 2017.

42 Reed et al. 2017.

43 ODIHR 2018, 12.
} 
Like the terrorism suppression conventions, such as the International Convention for the Suppression of Terrorist Bombings or the International Convention for the Suppression of the Financing of Terrorism ${ }^{44}$, the UN foreign fighters regime imposes obligations on states to criminalize, in domestic law, specified conduct as acts of terrorism. That is why the UN uses term "foreign terrorist fighters" (FTFs). However, unlike the treaty regime, the UN Security Council regime explicitly contemplates conduct related to an armed conflict. ${ }^{45}$ Resolution 2178 also offers a definition of FTF as: "individuals who travel to a State other than their States of residence or nationality for the purpose of the perpetration, planning, or preparation of, or participation in, terrorist acts or the providing or receiving of terrorist training, including in connection with armed conflict."

UNSC Resolution 2178 obliges states to criminalize actual or attempted travel for these purposes. The resolution does not define "terrorist acts". Instead, as argued by Moira Macmillan, "the 'terrorist' element of the crime that states are obliged to introduce is predicated on the conduct of the group the individual is travelling to join, rather than the individual's own conduct during the armed conflict". ${ }^{46}$ She further noticed that while UNSC Resolution 2178 also expresses particular concern about FTF recruitment by ISIL (Daesh), Al-Nusra Front (ANF), Al Qaeda, and affiliate and splinter groups designated under UNSC Resolutions 1267 and 1989, it is noteworthy that the definition of FTF and the obligation to criminalize conduct connected to travel is not restricted to individuals travelling to join these groups ${ }^{47}$, but any other terrorist groups as well.

Resolution 2396 (2017) on FTF returnees and relocators builds on previous resolutions. It particularly calls upon member states to share information on terrorists and to establish Advance Passengers Information (API) and Passenger Name Record (PNR) systems. The resolution urges the International Civil Aviation Organization (ICAO) to establish a standard for the collection, use, processing and protection of PNR data and decides that Member States shall develop watch lists or databases of known and suspected terrorists for use by law enforcement, border security, customs, military, and intelligence agencies. The resolution also encourages States to share this information through bilateral and multilateral mechanisms; decides that States shall develop and implement systems to collect biometric data in order to identify terrorists, including FTFs; and calls for the strengthening of international cooperation on legal access to digital data across borders.

The EU followed the Security Council resolutions. Directive 2017/541 on combating terrorism was adopted in March 2017, following the 2178 resolution and the Council of Europe's Additional Protocol to its Convention on the Prevention of Terrorism (adopted in 2015). In doing so, the directive updated the current EU framework and extended the list

\footnotetext{
44 See the list of other terrorism suppression conventions at: https://www.un.org/en/ counterterrorism/legal-instruments.shtml.

45 Macmillan 2018.

46 Macmillan 2018, 313.

47 Macmillan 2018, 313-314. 
of preparatory acts to be criminalized. Article 9 of the directive now includes a provision according to which the act of travelling to another country is criminalized if the intended purpose of that travel is to commit, contribute to or participate in terrorist offences, or to provide or receive training for terrorism. ${ }^{48}$ Article 10 stipulates that any act of organization or facilitation that assists any person in travelling for the purpose of terrorism, knowing that the assistance thus rendered is for that purpose, is punishable as a criminal offence when committed intentionally.

States that have criminalized foreign fighters can be divided in three loose categories: those which sanction such actions only if they are specifically related to terrorism (e.g. Denmark, Germany, Spain); those which sanction such actions if they are related not only to terrorism, but also to other so-called general crimes (e.g. Canada, Australia, UK); and those which sanction travelling abroad for the purpose of joining the conflict in general, i.e. irrespective of any crime-related intentions (Western Balkan countries). In most countries, planning to travel to a conflict area is not a crime unless there are clear indications that the individual aims to join a terrorist organization or to commit crimes or has already committed preparatory crimes. ${ }^{49}$ Similarly, individuals who return from a conflict zone can be usually charged only if certain specific criminally relevant behaviors are demonstrated. ${ }^{50}$ However, in the Western Balkans, which dispatched foreign fighters not only in Syria and Iraq but also in Ukraine, legislators decided to criminalize travelling abroad to join the conflict irrespective of its relations to terrorism.

\section{Foreign Fighters Legislation in the Western Balkans}

Ongoing conflicts, particularly, in Syria and Ukraine, have, besides attracting foreign fighters from the Western Balkans, also inspired some state officials to reminisce about conflicts in this region and the role of fighters that came to support local forces. The Ukrainian conflict revived Serbo-Croatian division on the line Orthodox-Catholic Christians. While Serbian (and Serbo-Bosnian) fighters recruited for Ukraine were appealed with, inter alia, the call to support Orthodox (pro-Russian) brothers against (Ukrainian) Catholic opponents, Croatian potential fighters were approached with the exact opposite call, i.e. to support Ukrainian (Catholic) brothers against offensive Russian (Orthodox) invaders. Already in 2015, Croatian then-Foreign Minister Vesna Pusić confirmed that some Croats are fighting for the government army in Ukraine, but denied they are fighting in paramilitary units. ${ }^{51}$ However, there are reports of Croats fighting for the Ukrainian Azov Battalion in the embattled Mariupol region of eastern Ukraine. ${ }^{52}$ The battalion is a

$48 \quad$ EU 2017.

49 Vidino et al. 2014, 5-6.

50 Ibid.

51 Milekic 2015.

52 See for instance: Colborne 2019. 
paramilitary militia functioning under the jurisdiction of the Ukrainian interior ministry but is seen as a far-right militia as it is led by the extreme nationalist Right Sector party. ${ }^{53}$

In 2015, Croatian Justice Minister Orsat Miljenić confirmed that Croatia had no plans to criminalize fighting in foreign armed conflicts, citing the country's own experience in the 1990s. He stated: "Let's go back to the Homeland War [1990s war in Croatia], when volunteers from around the world came and fought on our side, and we were very grateful that they came and helped us" ${ }^{54}$ He continued with "to say now that we will prohibit our citizens from going and to do the same somewhere else would not work due to our history, because we benefited in a similar way from that".55 Miljenić also tried to draw a distinction between going to fight in a purely local conflict and fighting for what he called "terrorist states, associations and movements" that threatened world order. ${ }^{56} \mathrm{He}$ asked: "If you or I go there [to Ukraine] and fight on one side, so what? What does it have to do with the Republic of Croatia?" He concluded with: "But, if someone, who is going to fight for someone whose objective is to demolish Western civilization, to destroy our country - he must go to jail" ${ }^{57}$

Miljenićs words proved to be truth. Croatia did not criminalize mere participation in armed conflict. Conversely, despite a shared history similar political and security concerns, all other Western Balkan countries have done so, either in 2014 or 2015. It was only in 2018 that Croatia amended legislation, but only in order to implement EU Directive 2017/541, in particular Article 9 related to travelling for the purpose of terrorism. In doing so, Croatia only criminalized travelling for the purpose of terrorism. ${ }^{58}$

The Western Balkan countries share all the key characteristics with Croatia (such as history, culture, politico-legal tradition, security challenges, etc.), including the track record of having foreign fighters in their armed formations during the conflict(s) in former Yugoslavia. Still, they have manifested much more anxiety in relation to recent foreign fighters trend than Croatia and other EU member states. As indicated, the Western Balkan countries went well beyond the requests from the UN Security Council resolutions, and opted to criminalize foreign fighting irrespective of its connection to terrorism.

In fact, Montenegro is the only Western Balkan country that explicitly connects participation in armed conflict abroad with terrorism (table 1). All others do not even mention terrorism, i.e. they criminalized participation in foreign military and paramilitary forma-

53 Milekic 2015.

54. As cited in: Milekic 2015.

55 Ibid.

56 In similar tone, the leader of the Self-determination movement in Kosovo, Albin Kurti, insisted that the foreign fighters legislation in Kosovo was generalized and neutral, as it does not differentiate fighting, for instance, for Kobane (Kurds) from fighting for ISIS (Radio Slobodna Evropa 2015).

57 As cited in: Milekic 2015.

58 Art. 15, Croatia - Amendments to the Criminal Code. 
tions. There are some slight differences when it is up to police/parapolice units, which are not explicitly mentioned in all countries from the region (table 1). Albanian law is the only one that does not mention police forces of any kind. However, this difference does not seem to be of vital importance, given that police forces often operate under military command during armed conflicts.

\begin{tabular}{|c|c|c|c|c|c|c|}
\hline $\begin{array}{l}\text { type of armed } \\
\text { formation / country }\end{array}$ & $\begin{array}{l}\text { North } \\
\text { Macedonia }\end{array}$ & Albania & Montenegro & Kosovo $^{* 59}$ & $\begin{array}{l}\text { Bosnia and } \\
\text { Herzegovina }\end{array}$ & Serbia \\
\hline army & $\mathrm{x}$ & $\mathrm{x}$ & $\mathrm{x}$ & $\mathrm{x}$ & $\mathrm{x}$ & $\mathrm{x}$ \\
\hline police & $\mathrm{x}$ & & $\mathrm{x}$ & $\mathrm{x}$ & & \\
\hline paramilitary & $\mathrm{x}$ & $\mathrm{x}$ & $\mathrm{x}$ & $\mathrm{x}$ & $\mathrm{x}$ & $\mathrm{x}$ \\
\hline parapolice & $\mathrm{x}$ & & $\mathrm{x}$ & $\mathrm{x}$ & $\mathrm{x}$ & \\
\hline $\begin{array}{l}\text { terrorist } \\
\text { organization }\end{array}$ & & & $\mathrm{x}$ & & & \\
\hline year ${ }^{60}$ & 2014 & 2014 & 2015 & 2015 & 2014 & 2014 \\
\hline
\end{tabular}

Table 1: Types of foreign armed formation forbidden to join in Western Balkans' legislation ${ }^{61}$

As per types of illegal activities, all countries have explicitly forbidden organization, recruitment, logistical support, public incitement to travel abroad, and the participation in an armed conflict abroad (table 2). Serbia is the only country that has not explicitly foreseen providing public support for travelling as a criminal offence. However, public incitement to commit terrorist acts is recognized as a separate criminal offence. ${ }^{62}$

59 This designation is without prejudice to positions on status, and is in line with UNSC 1244 and the ICJ Opinion on the Kosovo declaration of independence.

60 Year of the passage of new legislation.

61 Table made by the author, based on comparative analysis of relevant legislation, particularly: Art. 322a, Macedonia - Criminal Code; Article 265, Albania - Criminal Code; Art. 162b. Bosnia and Herzegovina - Amendments to the Criminal Code, 2014; Art. 386ab, Serbia - Amendments to the Criminal Code 2014; Art. 449b/6, Montenegro - Criminal Code; Kosovo* - Law on Prohibition of Joining the Armed Conflicts outside State Territory 2015.

62 Art. 391a, Serbia - Criminal Code. 


\begin{tabular}{|l|c|c|c|c|c|c|}
\hline $\begin{array}{l}\text { type of punishable } \\
\text { activities }\end{array}$ & $\begin{array}{c}\text { North } \\
\text { Macedonia }\end{array}$ & Albania & Montenegro & Kosovo* & $\begin{array}{c}\text { Bosnia and } \\
\text { Herzegovina }\end{array}$ & Serbia \\
\hline organization of FFs & $\mathrm{x}$ & $\mathrm{x}$ & $\mathrm{x}$ & $\mathrm{x}$ & $\mathrm{x}$ & $\mathrm{x}$ \\
\hline recruitment & $\mathrm{x}$ & $\mathrm{x}$ & $\mathrm{x}$ & $\mathrm{x}$ & $\mathrm{x}$ & $\mathrm{x}$ \\
\hline logistical support & $\mathrm{x}$ & $\mathrm{x}$ & $\mathrm{x}$ & $\mathrm{x}$ & $\mathrm{x}$ & $\mathrm{x}$ \\
\hline public support & $\mathrm{x}$ & $\mathrm{x}$ & $\mathrm{x}$ & $\mathrm{x}$ & $\mathrm{x}$ & \\
\hline participation & $\mathrm{x}$ & $\mathrm{x}$ & $\mathrm{x}$ & $\mathrm{x}$ & $\mathrm{x}$ & $\mathrm{x}$ \\
\hline
\end{tabular}

Table 2: Types of punishable activities related to FFs in Western Balkans' legislation

In all Western Balkan countries, foreign fighters-related criminal offences are punished by prison sentences (table 3). Durations of imprisonment vary depending on the severity of the crime. North Macedonia established only firm minimal sentences, i.e. at least four or five years, while other countries proscribed the range. Ten years is the longest possible sentence in Serbia, Montenegro and Bosnia and Herzegovina $(\mathrm{B} \& \mathrm{H})$, while Kosovo* and Albania envisaged much higher punishments, ranging from five (Kosovo) and eight (Albania) to maximum of 15 years. The shortest imprisonment is foreseen for public support.

\begin{tabular}{|l|c|c|c|c|c|c|}
\hline $\begin{array}{l}\text { type of punish- } \\
\text { able activities }\end{array}$ & $\begin{array}{c}\text { North } \\
\text { Macedonia }\end{array}$ & Albania & Montenegro & Kosovo* & $\begin{array}{c}\text { Bosnia and } \\
\text { Herzegovina }\end{array}$ & Serbia \\
\hline $\begin{array}{l}\text { organization } \\
\text { of FFs }\end{array}$ & $5+$ years & $8-15$ years & $2-10$ years & $5-15$ years & $8+$ years & $2-10$ years \\
\hline recruitment & $5+$ years & $8-15$ years & $2-10$ years & $5-15$ years & $1-10$ years & 2 - 10 years \\
\hline $\begin{array}{l}\text { logistical sup- } \\
\text { port }\end{array}$ & $5+$ years & $8-15$ years & $1-8$ years & $3-15$ years & $1-10$ years & $2-10$ years \\
\hline public support & $4+$ years & 3 - years & 6 mo $-5 \mathrm{y}$ & 6 mo $-5 \mathrm{y}$ & 3 mo -3 y & 6 mo-5 y \\
\hline participation & $4+$ years & $3-8$ years & 6 mo $-5 \mathrm{y}$ & $3-15$ years & $3+$ years & 6 \\
\hline
\end{tabular}

Table 3: Prison sentences for punishable activities related to FFs in Western Balkans' legislation

North Macedonia and Kosovo* explicitly proscribed that hiding of an offender (or the means used to commit the crime) of foreign fighter-related crimes is punishable by imprisonment of one to five years (in North Macedonia) ${ }^{65}$ and from six months up to five years in the case of Kosovo* ${ }^{66}$

63 Except if such criminal offence is committed in order to overthrow the constitutional order or to infringe the territorial integrity of a foreign state, then it is punishable by imprisonment from five to ten years (Article 265, Albania - Criminal Code).

64 Except if such act is committed within the group, the offender will be sentenced to one to eight years in prison (Art. 386a, Serbia - Amendments to the Criminal Code 2014). 
In all countries of the region, except in Albania where there is no explicit legal provision, a person who reveals (exposes) an individual or group and by doing so prevents the commission of a criminal offense may be exempted from sentence.

Finally, some of the countries, i.e. B\&H, Serbia and North Macedonia, made clear in their legislation to which categories of persons foreign fighters-related regulations will not be applied to. In $\mathrm{B} \& \mathrm{H}$, these provisions are not applicable to the persons who have acquired in a lawful manner the citizenship of a foreign country recognized by $\mathrm{B} \& \mathrm{H}$ in whose army or military formation they serve, or they serve in the military formations under control of governments internationally recognized by the United Nations. ${ }^{67} \mathrm{~A}$ national of a foreign country to which someone is travelling to from Serbia, or a member of an official mission of an international organization of which Serbia is a member, are exempt from application the foreign fighters provisions ${ }^{68}$ In North Macedonia, the offender who holds the citizenship of the state in whose regular military or police formations he/she participates or who is a member of military or paramilitary formations or police forces under the control of internationally recognized governments or international organizations shall not be punished. $^{69}$

\section{Criminalization as an Ineffective Strategy}

The Security Council's resolutions, discussed above, have underlined the importance of engaging relevant local communities and non-governmental actors in developing strategies to counter violent extremism. In resolution 2178, the Security Council also emphasized the importance of Member States' efforts to develop non-violent avenues for conflict prevention in order to decrease the risk of radicalization to terrorism, and underscored the role education can play in countering terrorist narratives. However, its focus and subsequent national responses have largely been concentrated on criminal measures. Below, I lay down main arguments for considering such an approach as ineffective. I use case-law from the Western Balkans to provide further evidence for my claims.

The first argument takes into consideration the reason for which the majority of foreign fighters actually join the conflict abroad. Existing research shows that what all these conflicts have in common is that insurgents consistently recruit foreign fighters by framing local wars as those that threaten their group's shared transnational identity, which, in turn, necessitates defensive mobilization. ${ }^{70}$ Accordingly, foreign fighters are attracted by frames that stress the existential threats to a particular identity group, regardless of what underlies it: ideology, religion, language, etc. ${ }^{71}$ "The mission is to deliver the message in

67 Art. 162b. Bosnia and Herzegovina - Amendments to the Criminal Code, 2014.

68 Art. 386, Serbia - Amendments to the Criminal Code 2014.

69 Art. 322a, Macedonia - Criminal Code.

70 For instance: Malet 2010, 97.

71 Glušac 2015, 35. 
such a way as to affect this 'sense of identity' of geographically distant individuals and thus trigger their involvement". ${ }^{72}$ Thus, from theoretical perspective, this phenomenon can be seen as a case of societal securitization. ${ }^{73}$ According to securitization theory, security is a (illocutionary) speech act, i.e. "by labeling something a security issue that it becomes one".74 By stating that a particular referent object is threatened in its existence, a securitizing actor claims a right to extraordinary measures to ensure the referent object's survival. ${ }^{75}$ As argued by Taureck, "when the audience accepts this call, the issue is then moved out of the sphere of normal politics into the realm of emergency politics, where it can be dealt with swiftly and without the normal (democratic) rules" ${ }^{76}$ To present an issue as an existential threat is to say that: "If we do not tackle this problem, everything else will be irrelevant (because we will not be here or will not be free to deal with it in our own way)." ${ }^{77}$ In societal security, the identity of a transnational group is a referent object, which should be protected by all means. ${ }^{78}$ When the states started to criminalize participation in the conflict abroad, they have only amplified the securitization discourse. A threat of criminal prosecution can actually strengthen potential recruits' sense that their transnational identity group indeed needs a defensive mobilization to tackle an existential threat. From a foreign fighter's perspective, such offensive reactions from the state only testify that their transnational group is indeed under threat, and that their active participation can contribute to common goal. Put differently, if someone is ready to participate in an armed conflict, knowing that there is a good chance that they may die, a threat of criminal prosecution would hardly change one's plans. In fact, it increases one's motivation. That is particularly true when someone's motivation is inspired by religious incentives, as is the case of some Bosnian fighters who followed the "fatwas" issued by extreme Islamic clerics calling for Jihad in Syria. ${ }^{79}$

In other words, while general preemptive logic of criminalization suggests that potential fighters would be leery of getting arrested and therefore give up on their plans ${ }^{80}$ to join foreign insurgences, in this context, the threat of getting arrested may, in return, reinforce their decision, as the survival of the transnational group (i.e. higher collective goal) may overpower personal interests and well-being. Existing research showed that "most European countries have also seen an upsurge in populist anti-immigrant parties who encourage the myth that the immigrants, especially Muslims, are taking over 'our' national soil and heritage". ${ }^{81}$ In such a context, Muslims are becoming even more alienated from the majority of their society, while at the same time, radical minority leaders "would like young Muslims to develop a more rigid Islamic identity, rejecting cultural integration and embracing cultural separatism", as noted by Kinnvall and Nesbitt-Larking. ${ }^{82}$ Same authors have also argued that when analyzing the socio-psychological forces encountered in the securitization of Islam, late adolescence in the contemporary West are seen as "years of existential anxiety and ontological doubt in which competing claims for belonging and

79 See for instance: Judgement 2015.

82 Ibid. 
affiliation are most acutely in tension". ${ }^{83}$ Building on the work of Arnett ${ }^{84}$, they further observed that "some young people find themselves adrift: at home neither in the local context nor in the global situation", motivating them to "search for alternative answers in mythologized traditions, fundamentalist religions or far-away nationalisms". ${ }^{85}$ The strength of religion as powerful identity signifier lies "in its ability to convey unity, security, and inclusiveness in times of crisis" ${ }^{86}$ To that end, it provides a "home", a place where "subjectivity can be anchored and securitized". ${ }^{87}$ And recruiters are very well aware of that. Altogether, when there is a combination of identity (particularly religious) incentives, rising hatred towards the West, and complex personal socio-psychological processes, a perfect setting for recruitment is created.

Secondly, criminal law should be subsidiary, meaning that it has ultima ratio character. In this case, criminal law is a political instrument. Criminal law is based on the "less can be more" principle, which implies that criminalization should be extraordinary and conceptualized as the ultimate legal instrument. Thus, it should be used to protect only the most valuable goods and values from the most severe threats and behaviors. Criminalization of foreign fighters is questionable both from the perspective of the object of criminal law protection and from the perspective of legitimacy. Criminalization of any behavior should be introduced only if there are realistic chances that such behavior can indeed be punished in a proper court procedure, meaning that sufficient evidence can be obtain in order to convict someone. In the case of criminalization of foreign fighters, this requirement is difficult to reach given that evidence depends greatly on international legal and intelligence cooperation between a state from which a foreign fighter travels and a state to which they travel.

Criminal prosecution of organizers or other types of facilitators that assists persons to travel for the purpose of terrorism is much easier as it happens on the territory of a prosecuting state. Thus, the state can use all criminal investigation tactics and measures to secure court-strong evidence. In contrast, prosecution for travelling and participating in a conflict abroad is much more complex, given that the state must prove that someone has indeed participated in the conflict. Very often the state receives information on someone's participation in the conflict through international intelligence sharing (cooperation). The problem is that information received through this channel can almost never be used in court (judicial) proceedings.

83 Kinnvall and Nesbitt-Larking 2009, 321.

84 Arnett 2002.

85 Kinnvall and Nesbitt-Larking 2009, 321.

86 Kinnvall 2004, 762-763.

87 Ibid. 
Intelligence sharing occurs when one state - the sender - communicates intelligence in its possession to another state - the recipient. ${ }^{88}$ Some of those intelligence cooperation agreements are formal, constituting legal instruments, but an important number of them are informal, based upon the common understanding between heads of the national intelligence services or other state officials. ${ }^{89}$

Allies routinely exchange intelligence through various bilateral and multilateral means, but the depth and breadth of these exchanges very much depend on their sharing of a common perception of a threat or sets of interests..$^{90}$ They usually cover a wide range of issues, including the sharing of assessments, raw data, or training facilities and the conduct of joint operations, some of which could lay dormant at any given time. ${ }^{91}$ Multilateral intelligence sharing arrangements also cover an array of potential activity between governments including, inter alia, information sharing, operational cooperation, facilities and equipment hosting, training and capacity building, and technical and financial support. ${ }^{92}$

Although there is wide agreement that international intelligence sharing is necessary for countering contemporary threats, its recent expansion has raised a number of potential problems that require vigilant oversight. ${ }^{93}$ Individuals are at greater risk of having their rights, especially their right to privacy, infringed upon. As noted by Kent Roach, individuals will rarely have the opportunity to challenge the accuracy of shared information because they will often be unaware that information about them has been shared and will not have access to that information. ${ }^{94}$

Probably the most obvious human right at risk in this case is the right not to be subject to torture or other forms of cruel, inhuman, or degrading treatment. For instance, "information sent to a foreign agency may be used by that agency in support of extrajudicial detention, torture, and even killings". ${ }^{95}$ Conversely, information received from a foreign agency may have been obtained through torture or be otherwise tainted. ${ }^{96}$ Thus, a special care should be taken when sending questions to foreign agencies, not only because they may invite the use of harsh interrogation tactics, but also because foreign agencies may use such questions in a way that is even less amenable to control by caveat. ${ }^{97}$ In principle, information should never be provided to a foreign country where there is a credible risk

88 See more in, for instance: Walsh 2007, 154.

89 See more in: Glušac 2018.

90 Taillon 2002, 174-175.

91 Ibid.

92 See more in: Cullen and Reddy 2016, 46.

93 Glušac 2018, 85.

94 Roach 2012, 131.

95 Glušac 2018, 85.

96 Roach 2012, 134.

97 Arar Commission 2006. 
that it will cause or contribute to the use of torture..$^{98}$ While this recommendation may seem idealistic, it indeed grasps the very credo of human rights-sensitive international intelligence sharing. ${ }^{99}$

For criminal prosecution of foreign fighters, the key question is whether intelligence received through international sharing schemes can be used before domestic courts or not. In general, that is not the case, given that most usually only information gathered in criminal investigations meets the legal requirements proscribed by international and national standards. Intelligence can be obtained by using different secret measures and tactics that do not meet court-strong threshold, i.e. as indicated above, intelligence can be retrieved by using illegal interrogation tactics, which was the case in numerous cases, especially during the so-called War on Terror. This is the reason why most states clearly separate the usage of special investigative measures for national security from those for criminal investigation purposes. Only the latter end up before the court. Intelligence agencies normally depend on sources that cannot be revealed in the courtroom and, consequently, challenged by the defense. However, it should be noted that examples of intelligence information presented as evidence in judicial practice are increasing, particularly in Canada, contributing to the notion of the "judicialization of intelligence". ${ }^{100}$ Nevertheless, this is still an evolving trend, far from a new judicial standard, especially when intelligence received through foreign exchange is in question.

\section{Foreign Fighters Case-Law in the Western Balkans}

The introduction of new criminal offences in the Western Balkans has happened in a highly political context. It has been primarily pushed by the security apparatus, without broad public consultation and with minor involvement of lawyers and criminologists. For these reasons, it was expected that the implementation of this legislation would also follow a similar pattern. In this regard, Western Balkan countries can be divided into two groups, depending on whether they have fighters only in the Middle East, or in Ukraine as well. The first group is consisted of North Macedonia, Albania and Kosovo*, while the second group is made of Serbia, B\&H and Montenegro.

Officials in North Macedonia estimate that 154 of their citizens have departed for Syria and Iraq, out of which approximately 80 fighters have returned. Sixteen of them have been charged with foreign fighting-related crimes and successfully prosecuted to conviction, with sentences ranging from two to seven years imprisonment. Most recently, a court in North Macedonia has jailed seven citizens, accusing them of fighting with the Islamic State group in Syria and Iraq. Six men were given six-year sentences for joining ISIL, while a seventh man was sentenced to nine years in prison after also being found

\footnotetext{
98 Arar Commission 2006, 345.See also: UN Human Rights Council 2010, 46.

99 Glušac 2018, 85.

100 Jimeno-Bulnes 2017, 178.
} 
guilty on charges of organizing a terrorist group. ${ }^{101}$ According to the same source, the suspects were arrested in Syria by international coalition forces and later handed over to Macedonian authorities in 2018. ${ }^{102}$ However, there is no substantial information available as to how they have been transferred to North Macedonia, or by whom, except that it was done "after a request by the United States". ${ }^{103}$ The fact that these fighters were arrested on the ground (battlefield), in flagrante delicto, made court proceedings considerably easier. However, in general, Macedonian authorities find it very challenging to acquire evidence of participation in the conflict abroad. According to the research published by the $\mathrm{Re}$ gional Cooperation Council (RCC), suspects "are typically charged for recruitment and support, rarely for participation in a terrorist group... [which] is probably an indication that police and prosecutors cannot secure enough evidence that would enable them to charge and prosecute some of these individuals." 104

The same challenge is observed in Albania, where none of approximately 40 individuals who have returned faced prosecution. ${ }^{105}$ Nevertheless, nine people in Albania have been charged with recruitment, and have been met with steep prison sentences, totaling 126 years. ${ }^{106}$ The three clerics, Bujar Hysa, Genci Balla and Gert Pashja, were found guilty of recruiting people for terrorist purposes, inciting hatred and making public calls for terrorist acts, and were sentenced respectively to 18,17 and 17 years in a high-security jail. ${ }^{107}$ According to information from their trial, they had preached in mosques not controlled by the official Muslim Committee and are believed to have recruited most of the 100 or so Albanians estimated to have traveled to Syria, some with their families, to fight alongside militant groups. ${ }^{108}$ The other six defendants were found guilty of the same charges but sentenced to shorter terms in jail. ${ }^{109}$ Albanian experience testifies that criminal prosecution of foreign fighters seems to be effective only for organization, financing and/or recruiting, as they happen on national soil, given that securing evidence is considerably easier, allowing the usage of wide range of investigative technics.

After the case of repatriation of seven North Macedonian fighters from Syria, a second and much larger operation was conducted by Kosovar authorities. In April 2019, they organized a return (repatriation) of 110 Kosovar citizens, mostly women and children ${ }^{110}$,

\footnotetext{
101 Associated Press 2019.

102 Associated Press 2019.

103 The Times 2018.

104 RCC 2017, 35.

105 RCC 2017, 29.

106 RCC 2017, 29.

107 Reuters 2016.

108 Ibid.

109 Ibid.

110 See more on women's roles in supporting, preventing \& fighting violent extremism in Kosovo in: Speckhard and Shajkovci 2017.
} 
from a camp in the Hassakeh province of northeastern Syria, where they were detained following the fall of Baghouz, the last stronghold of ISIL. ${ }^{111}$ This and similar camps have been under control of the Syrian Democratic Forces (SDF). Kurdish fighters have been the backbone of the U.S.-allied SDF, formed in 2015 as part of the campaign against the ISIL. Recently, the U.S. have played the critical role in facilitating repatriation of detainees from the SDF's camps to European countries. ${ }^{112}$ According to some sources, it is believed that there are approximately 2,000 foreign fighters under SDF custody, out of which just under 1,000 of them are believed to be Europeans. ${ }^{113}$ While such cooperation makes repatriation easier, it is still questionable what evidence gathered by SDF can actually be used in court proceedings in other countries, given that it is not always clear how the evidence has been acquired, i.e. if legal standards were respected or not. ${ }^{114}$

As it was the case in North Macedonia, this Kosovar repatriation mission was strongly supported by the U.S. In fact, Kosovar citizens were transported on a US military aircraft. While Kosovar authorities did not specify what role the U.S. had played, when asked about the return of fighters to Kosovo, U.S. military spokesman Sean Robertson said, "U.S. assets were used in support of this repatriation operation." 115 However, he added that "at no time did the U.S. take custody of the foreign terrorist fighter detainees." ${ }^{116}$ As reported by Reuters, Robertson declined to provide further details, citing security reasons. ${ }^{117}$ The U.S. Embassy in Pristina formally commended Kosovo for the return of its citizens and called other countries to do the same. ${ }^{118}$

In fact, already in 2017 when ISIL started losing territory, the Kosovar authorities began preparing to bring citizens home including providing medical help, psychiatric treatment and counseling, housing, social services, special education, and reintegration. ${ }^{119}$ In this regard, Kosovo departs from the practice of the number of Western nations, such as Australia or the Netherlands, who have revoked citizenship to foreign fighters in an effort to block their entry back home. This measure is considered to be in violation of international law. ${ }^{120}$ In most countries, as in Belgium, Denmark, and France, criminal conviction is an essential prerequisite to deprivation of citizenship. Germany has recently introduced a new provision regulating loss of citizenship in the Nationality Act. Under the new provision, German citizens with dual nationality, who take part in combat operations on behalf

111 Plesch and Haxhiaj 2019.

112 See more in: Speckhard and Shajkovci 2019.

113 Williams 2019.

114 Recently there are attempts to draft standards in this field. See more in: UN CTED 2020.

115 Bytyci 2019.

116 Ibid.

117 Ibid.

118 U.S. Embassy Pristina 2019.

119 Plesch and Haxhiaj 2019.

120 See for instance: Van Waas 2016, 469-487. 
of a terrorist militia outside Germany, will lose their German citizenship. ${ }^{121}$ According to the Federal Government, these amendments regulate future cases, "which ought to act as a deterrent to individuals considering leaving Germany for areas controlled by the ISIL terrorist group and to ISIL supporters". ${ }^{122}$ It should be noted that these new provisions will not apply to under-18-year-olds, nor can they be applied to ISIL fighters already being held outside Germany ${ }^{123}$, most notably in Syria.

The second group of Western Balkans countries is far more interesting as it enables us to see whether there are some differences in how the states implement the legislation depending on whether the fighters are returning from Syria or Ukraine.

Serbian authorities report that around 50 adult Serbian citizens (37 men and 12 women) have departed for Syria and Iraq, along with approximately 10 children. ${ }^{124}$ According to the Regional Cooperation Council, so far, 10 Serbian fighters have returned from ISILheld territory to Europe, but only four to Serbia; and all of these individuals have been charged with terrorist-related offenses. ${ }^{125}$ Three more suspected fighters are being tried in absentia, and efforts to locate them are being coordinated with Interpol. Criminal proceedings for those seven people were completed in March 2019, when the Court of Appeal in Belgrade confirmed the sentence by the Special Court ${ }^{126}$, which found them guilty of terrorism and cooperation with jihadi groups in Syria and Iraq. The court found them guilty of "collecting money from like-minded people in Serbia, the countries of the region and Western Europe, and financing the departure of several Serbian citizens who recruited to participate in armed conflicts, first in camps for terrorist training in Syria, and then on the battlefield". ${ }^{127}$ Those individuals were sentenced for terrorism-related criminal offences (Art. 391 of the Criminal Code), not for participation in conflict abroad, as a separate crime (Art. 386). Such qualification of the criminal offences was, arguably, done because most of the activities of these persons were conducted on Serbian soil, which enabled authorities to collect sufficient court-strong evidence.

In 2014, as warfare erupted in Ukraine between pro-Russian separatists in the east and Ukrainian fighters, many Russian sympathizers from the Balkans, mostly from Serbia, or Serbs from Bosnia and Herzegovina and Montenegro, joined pro-Russian paramilitary units operating in eastern Ukraine, mainly in the Donetsk area. ${ }^{128}$ Yet, returnees who fought in Ukraine have been treated very differently than those from the Middle East. Most of returned fighters from Ukraine have made a deal with the prosecution and pleaded guilty, receiving suspended sentences rather than time in prison. ${ }^{129}$ They were indicted for participation in conflict abroad (Art. 386), not terrorism-related offences. The exact terms of the settlements are not known or available to the public.

\section{Ibid.}

123 Ibid.

129 Ibid. 
Available documents from Belgrade's Higher Court detail which units Serbian fighters joined and describe how Serbs participated in the conflict, a number of the names of those convicted and some details about how they were organized have been blacked out from all court papers, including the verdicts. This information would normally be made public. It is also unclear how the fighters were arrested and whether they surrendered to the Serbian authorities. ${ }^{130}$

Interestingly, foreign fighters in Ukraine not only posted photos on social media of themselves holding rifles but they openly claimed that they took part in direct combat operations. ${ }^{131}$ According to some media outlets, social media posts from the Ukrainian battlefields have been indeed invaluable in enabling prosecutors in Serbia to prove the illegal military action of their nationals in Ukraine, i.e. sources from prosecutors' offices say YouTube videos and Facebook photos proved to be the key evidence in most cases. ${ }^{132}$

This difference in treatment presents not only a legal issue, but also a social and political one that, with time, could evolve into a serious security threat, according to some authors. ${ }^{133}$ Some local Muslim communities are interpreting such legal development as religious and ethnic discrimination, given that "Ukrainian" fighters are mostly ethnic Serbs and Orthodox Christians, pictured as patriots going to help Orthodox brothers in need. At the same time, "Syrian" fighters are mostly minorities and Muslims, labeled as potential terrorists. Serbian strategic documents in this area are certainly not helping to counter such views from the Muslim community given that, for instance, the National Strategy for the Prevention and Countering of Terrorism for 2017-2021 does not recognize extreme nationalism or right-wing nationalism at all, but is very much concentrated on radicalism and ethnically motivated extremism. ${ }^{134}$ That certainly does not contribute to strengthening inter-ethnic relations in the country.

Bosnia and Herzegovina $(\mathrm{B} \& \mathrm{H})$ has probably the richest case-law with regard to foreign fighters in the region. While Bosnian foreign fighters from Syria and Iraq started coming back in 2014, their number significantly increased in 2016, when ISIL started to lose its territory. Those who had returned in 2014, but before the enactment of amended legislation, could not be prosecuted for participation in conflict abroad. They were, thus, charged for a criminal act of organizing a terrorist group. Returnees claimed they were in Syria for educational purposes. ${ }^{135}$ Digital evidence retrieved from social networks proved to be crucial for prosecuting them. In a number of criminal proceedings photographs

\section{Ibid.}

131 For instance, Bratislav Živković, the leader of Serbian Chetnik unit "Jovan Šević", who returned from Ukraine spoke openly to media about taking part in combat operations. See Novosti 2014.

132 Ristic 2017.

133 Petrović and Stakić 2018, 33.

134 Serbia - National Strategy for the Prevention and Countering of Terrorism for 2017-2021.

135 Similarly happened in court cases in Serbia and Montenegro. 
retrieved from social media were used as evidence ${ }^{136}$, as well as video and audio material proving the presence of foreign fighters on battlefields.

According to Šikman, who gathered data from the Court of Bosnia and Herzegovina, 23 people were charged for the mentioned crimes in B\&H up to 2017, related to B\&H citizens leaving to country and becoming FTFs in Syria and Iraq. ${ }^{137}$ The majority of them were charged with organizing a terrorist group, 14 in total, while eight of them were charged with unlawful establishing and joining foreign paramilitary or parapolice formations. ${ }^{138}$ One person is charged for the criminal act of encouraging terrorist activities in public. ${ }^{139}$ Šikman notes that even though all of these individuals have been charged and sentenced, only in five cases the sentence was within the stipulated penalty, while 18 individuals were sentenced to prison terms that were lower than the prescribed and were in accordance with the Criminal Code. ${ }^{140}$ In these 18 cases, the court determined the existence of highly extenuating circumstances, such as family circumstances, their admission of doing the criminal acts, shorter time spent in Syria, sincere regret for the criminal acts, voluntary departure from the front, activities undertaken to deter people from going to Syria, cooperation with the persecuting bodies. ${ }^{141}$ In eight of these cases there was a plea bargain deal with the defendants. ${ }^{142}$

In December 2019, B\&H authorities organized the return of 25 ISIL fighters and their families from Syria to the country, in an operation facilitated by the U.S. Mike Pompeo, U.S. Secretary of State, formally thanked Bosnian authorities for this operation and commended SDF for "enabling this achievement" ${ }^{143}$ Vice versa, the Prosecutor's Office of B\&H expressed its gratitude to the U.S. Government and the U.S. Embassy in Sarajevo, for their support and assistance in the implementation of these activities. ${ }^{144}$ According to available information, court proceedings have started for seven returning fighters from this group who were put in detention immediately upon return, while six women and 12 children have been placed in the reception center in Delijaš, pending further legal actions. ${ }^{145}$

According to existing research, B\&H officials are not uniform in their assessment of the risk posed by returning foreign fighters and their families, but do acknowledge that they

\footnotetext{
136 See for instance: Judgement 2016a.

137 Šikman 2018, 130. Official records cite that most of Bosnian fighters have fought for ISIL, while the rest of the fighters joined the Al-Nusra Front (MS B\&H 2017, 35).

138 Šikman 2018, 130.

139 Šikman 2018, 130.

140 Šikman 2018, 130-131.

141 See more: Judgement 2016a; Judgement 2016b; Judgement 2017.

142 Šikman 2018, 131

143 As cited in: Sarajevo Times 2019.

144. Sarajevo Times 2019.

145 Komšić 2019. 
represent an unknown but potential threat to security. ${ }^{146}$ In its last available annual information on the state of security in the country, Ministry of Security of B\&H stated that returnees from the Syrian and Iraqi fronts are still a significant long-term security threat for the state. ${ }^{147}$ However, state officials agree that evaluating the threat posed by any individual should rely on case-by-case risk assessments. ${ }^{148}$

As per Bosnian citizens in Ukrainian conflict, most recent official data states that one national of B\&H died in Syria in 2017, fighting for pro-Russian forces, after he joined them from the Ukrainian theater. ${ }^{149}$ Authorities have identified one person who left B\&H to participate in armed conflict in Ukraine in 2017. ${ }^{150}$ With regard to the criminal proceedings, it was only in March 2019 that the Bosnian Prosecutor's office charged the first citizen (Gavrilo Stević) for joining foreign paramilitary or parapolice formations, namely pro-Russian forces in Eastern Ukraine. Stević was a member of paramilitary formation "Jovan Šević", mostly consisted of Serbian foreign fighters from different Balkan states. Allegedly, at least six more nationals of Bosnia and Herzegovina joined this paramilitary formation, but only Stević was formally charged. The indictment states that he was actively involved in armed conflict. ${ }^{151}$ In his first hearing before the court, Stević pleaded not guilty and claimed he was in Ukraine as a journalist.

It is highly unlikely that only a few fighters from Bosnia have joined the conflict in Ukraine. It seems that Bosnian authorities have concentrated much more on Syrian fighters, given well-known problems with Salafi radicals in some areas of the country, most notably in Gornja Maoča. ${ }^{152}$ However, it does not exculpate Bosnian authorities for judicial inactivity with regard to Ukrainian fighters, particularly taking into account their exposure on social networks.

According to the official data, between 2012 and 2018, total of 26 Montenegrin citizens have gone to Syria, out of which 18 men, five women and three children. Six men died in Syria, ten people are still in Syria or Turkey, while 10 of them returned to Montenegro. Since November 2015, the authorities registered no departure of Montenegrin citizens to Syria. As per Ukraine, Montenegrin official records contain data of "several" adult citizens of Montenegro who have all returned to the state. ${ }^{153}$ The same source reveals that two Montenegrin citizens have been sentenced for participating in armed conflict abroad, one for Syria, and one for Ukraine. The first sentence ever for this new criminal offence was

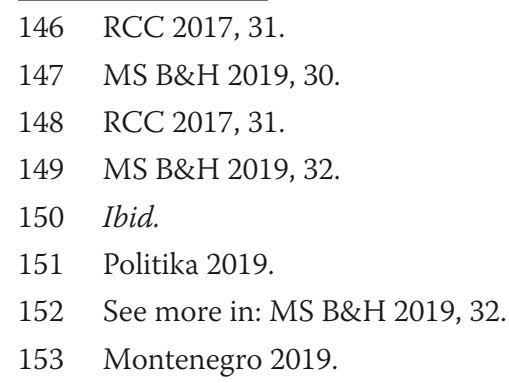


given in the case of Marko Barović, who was convicted for taking part in Ukrainian conflict. According to the court records, his military card showed that he served in Donetsk People's Republic initially as a driver and later as a sniper. ${ }^{154}$ Montenegrin prosecutors say the key proof that he fought in Ukraine and did not just drive a truck, as he claimed initially at the trial, was his Facebook profile. ${ }^{155} \mathrm{He}$ often posted photos from the battlefield of himself in uniform and holding a rifle. The posts and photos, which were public, were admitted as evidence before the court in Podgorica. After being confronted with the evidence, Barović confessed spending time in Ukraine. ${ }^{156}$ A year later (2018), Hamid Berović was convicted on the same grounds, for participation in Syrian conflict and was sentenced to six months in prison. He was released on parole for good behavior. For both Barović and Berović, individual treatment programs were designed, according to Montenegrin authorities. $^{157}$

Montenegrin authorities manifested more consistency and equality then Serbian and Bosnian in treating fighters from Syria and Ukraine. Serbia and B\&H have hesitated to prosecute "Ukrainians" or have suspended their sentences, while they have invested considerable efforts in trying to convict "Syrians" for terrorism-related offences, rather just participation in conflict abroad. It is reasonable to think that risk assessments for fighters returning from Ukraine indicated they do not present a serious threat to society, otherwise plea agreements would not been made. The case-law from Serbia and B\&H testifies that foreign fighters legislation has been adopted anxiously and hastily, while its implementation has been much more calculated. The implementation suggests that there was no real need for such broad legal provisions aiming at foreign fighters. If there are sufficient bases for indicting someone for terrorism-related offence, the authorities opt for that option, not participation in conflict abroad. At the same time, in cases where there are no terrorist intentions, risk assessments would most probably show low risk and accused persons would be eligible for plea agreement, as it was the case in Serbia.

\section{A Way Forward}

In this article, I aimed to demonstrate that countering foreign fighters phenomenon predominantly by criminal prosecution is an ineffective and to some extent even counterproductive strategy, especially in case of the Western Balkan countries which introduced broader legislative changes, criminalizing participation in conflict abroad irrespective of connection with terrorism. Existing academic research and court proceedings in the Western Balkans have already showed that both on-ground and on-line recruiters of foreign fighters are using identity security discourse, primarily aiming at religious incentives of potential recruits, to attract them to join conflicts abroad. In case of Syria and Iraq

\footnotetext{
154 Ristic 2017.

155 Ibid.

156 Ibid.

157 Montenegro 2019. 
such a call is framed in Jihad narrative, while fighters recruited for Ukraine were appealed with the call to support Orthodox brothers against Catholic enemies, or vice versa. In other words, foreign fighters were recruited by being persuaded that they are faced with a potentially existential threat as members of a particular group. In such a frame, further threat by punitive (criminal) measures can hardly deter them from mobilization; in fact, criminal prosecution may even further encourage the existence-threatening discourse and make it seem that the fight is even more necessary for survival. ${ }^{158}$

The implementation of legislation, especially criminal law should be clear, certain, predictable and as free of political influence as possible. The law itself should clearly differentiate between criminal offences, shrinking the space for non-judicial calculations. In this article, I demonstrated that the existing case-law in the Western Balkans show that national authorities in countries with both Middle East and Ukrainian fighters are not always investing equal efforts to prosecute them, nor they indict them for same criminal offences. Whether someone poses a threat to society is one of the valid assessments the court conducts during the criminal proceedings. However, it should not be the factor in deciding what criminal offence someone should be charged for.

Furthermore, this research showed that criminal prosecution of foreign fighters in the Western Balkans proved to be effective only for organization, financing and/or recruiting, as they happen on national soil, given that securing evidence is considerably easier, allowing the usage of a wide range of investigative measures. The cited case-law in Serbia and $\mathrm{B} \& \mathrm{H}$ illustrated that. However, prosecuting foreign fighters post festum (upon their return) is a different story. Besides the question of whether and if so, who, and for what charges, to prosecute, collecting evidence in the context of foreign fighters cases has clearly been a major challenge. Case-law from the Western Balkans demonstrates that the key evidence for prosecuting foreign fighters for participation in armed conflicts abroad was obtained through social media. In addition, cross-border bilateral legal cooperation that may seem as a hopeful avenue has been mostly fruitless, which was expectable, as it is hard to imagine that national authorities would, in the midst of widespread armed conflict on its own territory, invest resources of securing court-strong evidence in individual cases for the purposes of criminal proceedings in other countries. Examples from North Macedonia, Kosovo and Bosnia and Herzegovina, presented in this article, testify that foreign fighters were apprehended by the coalition forces on the ground in Syria, and then repatriated to the Western Balkans in operations conducted, or at least supervised, by the U.S. and SDF, and not formal Syrian authorities. However, such repatriation arrangements were made only for groups and would not be cost-effective in individual cases. In other words, if someone participates in the conflict abroad and does not make any careless public manifestation, including on social media, that can self-indict them, and was not caught in flagrante on the battlefield, it would be very challenging to secure sufficient court-strong evidence to indict them. 
It remains unclear why the Western Balkan countries opted for a much broader criminalization of foreign fighters than the Security Council asked for. In general, countries from the region do have a very active legislative agenda, because of the EU accession process, i.e. they have to harmonize their legislation with Acquis Communautaire. However, if they were aiming to align with the EU policy in this regard, they should have done what Croatia did, that is, implement anti-terrorism Directive. Instead, they adopted a broader legislative approach without clear justifications. Adopting such formally strong and seemingly resolute, but ultimately ineffective legislative measures is not a rare practice in the region. In fact, laws are often changed, including criminal laws that should be amended only after thorough analysis. For instance, the Serbian Criminal Code was amended in 2012, 2013, 2014, 2016 and 2019. Hasty legislative changes do not contribute to legal certainty nor do they stabilize the legal system, but may serve as a show-off mechanism for the international community, in being "a more Catholic than the Pope" fashion, so easily used by weak states with strong leaders.

While the countries from the region have criminalized foreign fighting swiftly after the UN resolutions (in 2014/15), already at that time the number of fighters from the Western Balkans was in noticeable decline, the trend that has continued to date. ${ }^{159}$ To that end, it is very difficult to assess whether criminalization as such have had any real impact on those wishing to leave. Foreign fighters and their families that have been recently repatriated back to the region mostly went to Syria before criminalization was introduced.

Evidence from judicial practice, particularly in Serbia and B\&H suggests that foreign fighters legislation has been adopted anxiously and under urgent procedure, while its implementation has been more calculated. The implementation indicates that there was no real need for such broad legal provisions aimed at foreign fighters. Legislation, especially a poorly implemented one, cannot on its own resolve complex social, political and economic issues, such as the foreign fighter phenomenon. Comprehensive preventive activities implemented on a local level may contribute much more to that goal. "The ultimate solution to foreign fighter recruitments is to diminish the salience of the transnational groups through which recruitment is conducted" ${ }^{160}$ As argued elsewhere, "foreign fighter recruiters tend to be active in sub-culture groups, to which immigrants often turn, because they do not establish strong enough links with the majority population, not even with their own local, among other religious, community." 161 More contact through alternative social channels strengthens particular identities and connections with other members. The result is a willingness to fight for them, because "they identify more closely with other members abroad than they do with fellow citizens of the state in which they reside". ${ }^{162}$

\footnotetext{
159 I thank the anonymous reviewer for bringing this point to my attention.

160 Glušac 2015, 46.

161 Ibid.

162 Malet 2010, 113. 
Ultimately, the focus should be on efforts to (re)integrate alienated members of society with their immediate communities. ${ }^{163}$ In order for this to happen, members of majority communities have to be willing to do so, meaning that discourses describing majority communities as 'indigenous', as 'sons of the soil', as 'true inhabitants,' ${ }^{164}$ have to be abandoned. As argued by Kinnvall and Nesbitt-Larking, "only through serious attempts at securitizing space and subjectivity, that is by removing structural and psychological fears of the other through a deep transnational multiculturalism that recognizes multicultural space and multicultural (hybrid) subjectivities, and by promoting social, economic, political and psychological integration, can these mutual sets of securitization processes be addressed". 165

Reintegration as a long-term strategy is challenging for implementation, but remains the best one available, both before and after someone's participation in armed conflict abroad. Reintegration refers to the reestablishment of social, familial, and community ties and positive participation in society. ${ }^{166}$ Holmer and Shtuni argue that "developing successful reintegration programs is crucial not only to preventing recidivism among returnees but also to mitigating further radicalization among the youth population and building overall community-level resilience to violent extremism". ${ }^{167}$ Rehabilitation and deradicalization are important elements of the reintegration strategy and refer to cognitive disassociation from a violent group identity and ideology. ${ }^{168}$ By rehabilitation programs I consider "any purposeful, planned intervention, which aims to change the characteristics of the offender (attitudes, cognitive skills and processes, personality or mental health, and social, educational or vocational skills) that are believed to be the cause of the individual's criminal behavior, with the intention to reduce the chance that the individual will re-offend". ${ }^{69}$ While the states have adopted different rehabilitation strategies ${ }^{170}$, rehabilitation programs require multi-disciplinary teams of experts able to create individual programs, based on the personal characteristics of the rehabilitee. Finally, taking into account that geographical hot spots - where radicalization has been successful in the past - are already well mapped in the Western Balkans (e.g. Gornja Maoča), governments should concentrate on them, particularly given the scarcity of resources.

\footnotetext{
163 Glušac 2015, 46.

164 Kinnvall and Nesbitt-Larking 2009, 321.

165 Ibid.

166 Holmer and Shtuni 2017. See more on reintegration in: UNODC 2018.

167 Holmer and Shtuni 2017, 2.

168 Šikman 2018, 132.

169 Veldhuis 2012, 2.

170 See more in: Mehra 2016, 20.
} 


\section{References}

Albania - Criminal Code, Law No. 7895/1995, amended by Law No. 36/2017 and $89 / 2017$.

Arielli, Nir. 2018. From Byron to bin Laden: A History of Foreign War Volunteers. Cambridge: Harvard University Press.

Arnett, Jeffrey. 2002. “The Psychology of Globalization.” American Psychologist 57 (10): 774-783.

Associated Press. 2019. "North Macedonia jails 7 IS fighters captured in Syria”. March 21. Accessed October 10, 2019. https://www.apnews.com/fa8d555236ae4470977ebd555e01dcb2.

Bojović, Aleksandar. 2016. "Džihadisti se od zakona štite potvrdama o školovanju”, Politika, November 27, Accessed June 10, 2019. http://www.politika.rs/sr/clanak/368805/Dzihadisti-se-od-zakona-stite-potvrdama-o-skolovanju.

Bosnia and Herzegovina - Amendments to the Criminal Code, "Official Gazette of Bosnia and Herzegovina", No. 47/2014.

Bosnia and Herzegovina - Criminal Code, "Official Gazette of Bosnia and Herzegovina”, Nos. 2003, 32/2003 - corr., 37/2003, 54/2004, 61/2004, 30/2005, 53/2006, $55 / 2006,8 / 2010,47 / 2014,22 / 2015,40 / 2015$ and 35/2018.

Bosnia and Herzegovina - Ministry of Security. 2019. "Informacija o stanju sigurnosti u Bosni i Hercegovini u 2017. godini”. Accessed September 6, 2019. http://msb. gov.ba/PDF/050720196.pdf.

Bosnia and Herzegovina - Ministry of Security. 2017. "Informacija o stanju sigurnosti u Bosni i Hercegovini u 2016. godini”. Accessed September 6, 2019. http://msb. gov.ba/PDF/info2017.pdf.

Buzan, Barry, Ole Waever, and Jaap de Wilde. 1998. Security: A New Framework for Analysis. London: Lynne Rienner.

Bytyci, Fatos. 2019. "Kosovo brings back fighters, families of jihadists from Syria". Reuters. April 20. Accessed September 6, 2019. https://www.reuters.com/article/uskosovo-syria/kosovo-brings-back-fighters-families-of-jihadists-from-syria-idUSKCN1RW003.

Cesari, Joselyne. 2012. "Securitization of Islam in Europe." Die Welt des Islams 52 (3-4): 430-449. 
Colborne, Michael. 2019. "Croatia Key to Ukrainian Far-Right's International Ambitions". Balkan Insight. July 18. Accessed October 9, 2019. https://balkaninsight. com/2019/07/18/croatia-key-to-ukrainian-far-rights-international-ambitions/.

Commission of Inquiry into the Actions of Canadian Officials in Relation to Maher Arar. 2006. Report of the Events Relating to Maher Arar: Analysis and Recommendations. Ottawa: Privy Council.

Council of the European Union. 2014. "Foreign Fighters and Returnees”. EU CounterTerrorism Coordinator, 15715/14. November 24. Accessed June 10, 2019. http:// statewatch.org/news/2014/nov/eu-council-foreign-fighters-discussionpaper15715-14.pdf.

Cragin, Kim. 2017. “The Challenge of Foreign Fighter Returnees." Journal of Contemporary Criminal Justice 33 (3): 292-312.

Croatia - Criminal Code, "Official Gazette of the Republic of Croatia”, Nos. $125 / 2011,144 / 2012,56 / 2015,61 / 2015,101 / 2017,118 / 2018$.

Croatia - Amendments to the Criminal Code, Official Gazette of the Republic of Croatia”, No. 118/2018.

Croatia - Final Draft Law on Amendments to the Criminal Code. 2018. Accessed September 6, 2019. https://vlada.gov.hr/UserDocsImages//2016/

Sjednice/2018/12\%20prosinac/129\%20sjednica\%20VRH//129\%20-\%204.pdf.

Cullen, Michael, and Dame Patsy Reddy. 2016. Intelligence and Security in a Free Society: Report of the First Independent Review of Intelligence and Security in New Zealand.

European Parliamentary Research Service. 2018. The Return of Foreign Fighters to EU Soil: Ex-Post Evaluation.

European Union. 2017. "Directive (EU) 2017/541 of the European Parliament and of the Council of 15 March 2017 on combating terrorism and replacing Council Framework Decision 2002/475/JHA and amending Council Decision 2005/671/JHA".

Europol. 2016. European Union Terrorism Situation and Trend Report 2016.

Gardner, Frank. 2013. "Europe Could Feel the Backlash from Jihadist Conflicts", $B B C$, November 30. Accessed June 10, 2019. http://www.bbc.com/news/world- middleeast-25155188. 
Germany - Federal Chancellor. 2019. “German passport can be revoked”, April 3. Accessed January 28, 2020. https://www.bundesregierung.de/breg-en/chancellor/ german-passport-can-be-revoked-1597456.

Glušac, Luka. 2015. "Foreign (Terrorist) Fighters," In The OSCE and Contemporary Security Challenges, 33-48. Belgrade: OSCE Mission to Serbia.

Glušac, Luka. 2018. "International Intelligence Sharing: Key Preconditions for an Effective Oversight," In The Proceedings of the 4th International Academic Conference on Human Security. edited by Stanarević, Svetlana, Goran J. Mandić, and Ljubnka Katić, 83-88. Belgrade: University of Belgrade - Faculty of Security Studies.

"Greater Cooperation Needed to Tackle Danger Posed by Returning Foreign Fighters, Head of Counter-Terrorism Office Tells Security Council," United Nations, November 19, 2017.

Hegghammer, Thomas. 2010. "The Rise of Muslim Foreign Fighters: Islam and the Globalization of Jihad." International Security 35 (3): 53-91.

Hegghammer, Thomas. 2013. "Should I Stay or Should I Go? Explaining Variation in Western Jihadists' Choice between Domestic and Foreign Fighting," American Political Science Review 107 (1): 1-15.

Hegghammer. Thomas and Petter Nesser. 2015. "Assessing the Islamic State's Commitment to Attacking the West." Perspectives on Terrorism 9 (4): 14-30.

Helfont, Tally. 2001. “The Foreign Fighters Problem, Recent Trends and Case Studies." In The Foreign Fighters Problem, Recent Trends and Case Studies: Selected Essays, edited by Michael P. Noonan. Philadelphia: Foreign Policy Research Institute.

Holman, Timothy. 2016. "Gonna Get Myself Connected: The Role of Facilitation in Foreign Fighter Mobilizations.” Perspectives on Terrorism 10 (2): 1-23.

Holmer, Georgia and Adrian Shtuni. 2017. "Returning Foreign Fighters and the Reintegration Imperative”, Special Report 402. Washington, DC: United States Institute of Peace, Accessed September 22, 2019. https://www.usip.org/sites/default/ files/2017-03/sr402-returning-foreign-fighters-and-the-reintegration-imperative.pdf.

Jimeno-Bulnes, Mar. 2017. "The Use of Intelligence Information in Criminal Procedure: A Challenge to Defence Rights in the European and the Spanish Panorama." New Journal of European Criminal Law 8 (2): 171-191.

Judgement of the Court of Bosnia and Herzegovina. 2015. No. S1 2 K $01796815 \mathrm{~K}$ of 05 November 2015. 
Judgement of the Court of Bosnia and Herzegovina. 2016a. No. S 12 K $01899115 \mathrm{~K}$ of 31 October 2016.

Judgement of the Court of Bosnia and Herzegovina. 2016b. No. S1 2 K 02211216 Ko of 16 August 2016.

Judgement of the Court of Bosnia and Herzegovina. 2017. No. S 12 K 02119817 Kžk of 22 November 2017.

Kinnvall, Catarina and Paul Nesbitt-Larking. 2010. “The political psychology of (de) securitization: place-making strategies in Denmark, Sweden, and Canada." Environment and Planning D: Society and Space 28: 1051-1070.

Kinnvall, Catarina and Paul Nesbitt-Larking. 2009. "Security, subjectivity and space in postcolonial Europe: Muslims in the diaspora." European Security 18 (3): 305-325,

Kinnvall, Catarina. 2004. "Globalization and Religious Nationalism: Self, Identity, and the Search for Ontological Security." Political Psychology 25 (5): 741-767.

Komšić, Zvonko. 2019. "Nakon godina provedenih na ratištu u Siriji prijeti im zatvor u BiH." N1, December 24, Accessed January 28, 2020. http://ba.n1info.com/Vijesti/ a399884/Nakon-godina-provedenih-na-ratistu-u-Siriji-prijeti-im-zatvor-u-BiH.html.

Kosovo* - Law on Prohibition of Joining the Armed Conflicts outside State Territory, No. 05/L-002, 2015.

Kursani, Shpend. 2018. Western Balkans Extremism Research Forum - Serbia Report. London: British Council.

Mackinlay, John. 2002. “Globalization and Insurgency." Adelphi Papers No. 352. London: International Institute for Strategic Studies.

Macmillan, Moira. 2018. “The UN Foreign (Terrorist) Fighter Regime and International Criminal Law”, ASIL Proceedings. doi:10.1017/amp.2019.27.

Malet, David and Rachel Hayes. 2018. "Foreign Fighter Returnees: An Indefinite Threat?" Terrorism and Political Violence, DOI: 10.1080/09546553.2018.1497987.

Malet, David. 2010. "Why Foreign Fighters? Historical Perspectives and Solutions." Orbis: A Journal of World Affairs 54 (1): 97-114.

Malet, David. 2013. Foreign Fighters: Transnational Identity in Civil Conflicts. New York: Oxford University Press. 
Malet, David. 2008. “Foreign Fighters: Transnational Identity in Civil Conflicts”. Ph. diss., George Washington University.

Mavelli, Luca. 2013. "Between Normalisation and Exception: The Securitisation of Islam and the Construction of the Secular Subject." Millennium: Journal of International Studies 41 (2): 159-181.

Mehra, Tanya. 2016. "Foreign Terrorist Fighters: Trends, Dynamics and Policy Responses". ICCT Report, The Hague: The International Centre for Counter-Terrorism. Accessed September 22, 2019. https://icct.nl/wp-content/uploads/2016/12/ICCTMehra-FTF-Dec2016-2.pdf.

Mendelsohn, Barak. 2011. "Foreign Fighters-Recent Trends." Orbis: A Journal of World Affairs 55 (2): 189-202.

Milekic, Sven. 2015. "Some Croats Fighting in Ukraine Army, Pusic says". Balkan Insight. February 12. Accessed September 22, 2019. https://balkaninsight. com/2015/02/12/croatia-not-prosecuting-fighters-in-foreign-wars/.

Moreng, Bridget. 2016. “ISIS’ Virtual Puppeteers: How they recruit and train "Lone wolves." Foreign Affairs, September 21.

Montenegro - Criminal Code, “Official Gazette of the Republic of Montenegro”, Nos. 70/2003, 13/2004 - corr. and 47/2006, and "Official Gazette of Montenegro", Nos. 40/2008, 25/2010, 32/2011, 64/2011 - other law, 40/2013, 56/2013 - corr., 14/2015, 42/2015, 58/2015 - other law, 44/2017 and 49/2018.

Montenegro, The Government - Bureau for Operational Coordination, Provisional Action Plan for 2019 for Implementation of the Action Plan for Implementation of the Countering Violent Extremism Strategy 2016-2018, Podgorica, January 2019, Accessed September 22, 2019. http://www.gov.me/ResourceManager/FileDownload. aspx?rId=346918\&rType $=2$.

Nezavisne. 2019. “Džihadistima iz Sirije lisice na ruke čim kroče u BiH”. March 14. Accessed September 22, 2019. https://www.nezavisne.com/novosti/bih/Dzihadistima-iz-Sirije-lisice-na-ruke-cim-kroce-u-BiH/527539.

North Macedonia - Criminal Code, Consolidated Text, "Official Gazette of the Republic of Macedonia”, Nos. 37/1996, 80/1999, 4/2002, 43/2003, 19/2004, 81/2005, 60/2006, 73/2006, 7/2008, 139/2008, 114/2009, 51/2011, 135/2011, 185/2011, 142/2012, 166/2012, 55/2013, 82/2013, 14/2014, 27/2014, 28/2014, 41/2014, 
$115 / 2014,132 / 2014,160 / 2014,199 / 2014,196 / 2015,226 / 2015,97 / 2017$ and 248/2018) https://www.refworld.org/docid/5aa108434.html.

"Now that the Islamic State has fallen in Iraq and Syria, where are all its fighters going", the Washington Post, February 22, 2018.

ODIHR. 2018. Guidelines for Addressing the Threats and Challenges of Foreign Terrorist Fighters, Vienna: OSCE.

Petrović, Predrag and Isidora Stakić. 2018. Western Balkans Extremism Research Forum - Serbia Report. London: British Council.

"Podignuta optužnica protiv Srbina iz BiH zbog Ukrajine”. 2019. Politika, 26 March, Accessed September 22, 2019. http://www.politika.rs/sr/clanak/425917/Podignutaoptuznica-protiv-Srbina-iz-BiH-zbog-Ukrajine.

Radio Slobodna Evropa.2015." Nacrt zakona o zabrani učešća na stranim ratištima usvojen u načelu“, 23 Januar. Accessed September 05, 2019. https://www. slobodnaevropa.org/a/nacrt-zakona-o-zabrani-ucesca-na-stranim-ratistima-usvojenu-nacelu/26809901.html.

Reed, Alastair, Johanna Pohl and Marjolein Jegerings. 2017. “The Four Dimensions of the Foreign Fighter Threat: Making Sense of an Evolving Phenomenon”, ICCT. Accessed June 10, 2019. https://icct.nl/wpcontent/uploads/2017/06/ICCT-Reed-PohlThe-Four-Dimensions-of-the-Foreign-Fighters-Threat-June-2017.pdf.

Regional Cooperation Council. 2017. A Waiting Game: Assessing and Responding to the Threat from Returning Foreign Fighters in the Western Balkans. Sarajevo: RCC.

Reuters. 2016. Albanian court jails nine for recruiting fighters for Syria. May 3. Accessed October 05, 2019. https://www.reuters.com/article/us-mideast-crisis-syria-albania/albanian-court-jails-nine-for-recruiting-fighters-for-syria-idUSKCNOXU2AB.

Ristic, Marija. 2017. "Facebook Reveals Serbian Fighters' Role in Ukraine War”, Balkan Insight, December 27, Accessed September 22, 2019. https://balkaninsight.com/2017/12/27/facebook-reveals-serbian-fighters-role-in-ukrainewar-12-25-2017/.

Roach, Kent. 2012. "Overseeing Information Sharing," In Overseeing Intelligence Services: A Toolkit. edited by Born, Hans and Aidan Wills, 129-150. Geneva: DCAF.

Plesch, Valerie and Serbeze Haxhiaj. 2019. "Kosovo is trying to reintegrate ISIL returnees. Will it work?”, Aljazeera, Jun 9, Accessed September 22, 2019. 
https://www.aljazeera.com/indepth/features/kosovo-reintegrate-isil-returneeswork-190608200858002.html.

Politika. 2019. "Džihadiste iz Sirije prebacuju u zatvore u BiH”. October 8. Accessed October 9, 2019. http://www.politika.rs/sr/clanak/439407/Dzihadiste-iz-Sirijeprebacuju-u-zatvore-u-BiH.

Salehyan, Idean. 2009. Rebels without Borders: Transnational Insurgencies in World Politics. Ithaca: Cornell University Press.

Sarajevo Times. 2019. "US Secretary of State thanked Bosnia-Herzegovina after Return of 25 ISIL Fighters”, December 22, Accessed January 28, 2020. https://www. sarajevotimes.com/us-secretary-of-state-thanked-bosnia-herzegovina-after-returnof-25-isil-fighters/.

Speckhard, Anne, and Ardian Shajkovci. 2019. "Who Are the ISIS Fighters in Custody, and How Can They Be Repatriated?" HSToday, October 7, Accessed January 28, 2020. https://www.hstoday.us/subject-matter-areas/counterterrorism/who-are-theisis-fighters-in-custody-and-how-can-they-be-repatriated/.

Speckhard, Anne, and Ardian Shajkovci. 2018. “The Balkan Jihad: Recruitment to Violent Extremism and Issues Facing Returning Foreign Fighters in Kosovo and Southern Serbia." Soundings: An Interdisciplinary Journal 101 (2): 79-109.

Speckhard, Anne, and Ardian Shajkovci. 2017. Drivers of Radicalization and Violent Extremism in Kosovo: Women's Roles in Supporting, Preventing E Fighting Violent Extremism. Washington: International Center for the Study of Violent Extremism.

See, Sylvene. 2018. "Returning Foreign Terrorist Fighters: A Catalyst for Recidivism Among Disengaged Terrorists." Counter Terrorist Trends and Analyses 10 (6): 7-15.

Serbia - Criminal Code. 2019. “Official Gazette of RS“, Nos. 85/2005, 88/2005 - corr., $107 / 2005$ - corr., $72 / 2009,111 / 2009,121 / 2012,104 / 2013,108 / 2014,94 / 2016$ and $35 / 2019$.

Serbia - Amendments to the Criminal Code. 2014. "Official Gazette of RS“, No. $108 / 2014$.

Serbia - National Strategy for the Prevention and Countering of Terrorism for 20172021, Accessed September 22, 2019. https://rm.coe.int/serbian-national-strategy-forthe-prevention-and-countering-of-terrori/168088ae0b.

Šikman. Mile. 2018. "Return of the Foreign Terrorist Fighters - Criminal Persecution and Deradicalization," In Violent Extremism and Radicalization Processes as Driving 
Factors to Terrorism Threats, edited by Čaleta, Denis and Corinna A. Robinson, 109136. Ljubljana: Ministry of Defense of Slovenia, Joint Special Operations University from Tampa, USA and Institute for Corporative Security Studies.

Soufan Group. 2015. "Foreign Fighters: An Updated Assessment of the Flow of Foreign Fighters into Syria and Iraq".

Taillon, Paul. 2002. Hijacking and Hostages: Government Responses to Terrorism. Westport: Praeger.

Taureck, Rita. 2006. "Securitization Theory and Securitization Studies." Journal of International Relations and Development 9: 53-61.

"The Challenge of Returning and Relocating Foreign Terrorist Fighters: Research Perspectives," UN Counter-Terrorism Committee Executive Directorate (UNCTED), March 2018.

The Times. 2018. "Macedonia takes back 7 Isis prisoners from Syria”. August 8. Accessed October 9, 2019. https://www.thetimes.co.uk/article/macedonia-takes-back7-isis-prisoners-from-syria-wk60rqrmf.

The U.S. Embassy in Pristina. 2019. Statement from U.S. Embassy Pristina. April 20. Accessed September 22, 2019. https://xk.usembassy.gov/statement-from-u-s-embassy-pristina-6/.

UN CTED. 2020. Guidelines to Facilitate the Use and Admissibility as Evidence in National Criminal Courts of Information Collected, Handled, Preserved and Shared by the Military to Prosecute Terrorist Offences ('Military Evidence'). Accessed January 28, 2020. https://www.un.org/sc/ctc/wp-content/uploads/2020/01/Battlefield_Evidence_Final.pdf.

UN Human Rights Council. 2010. Report of the Special Rapporteur on the promotion and protection of human rights and fundamental freedoms while countering terrorism. A/HRC/16/51.

UN Office on Drugs and Crime (UNODC). 2018. Introductory Handbook on the Prevention of Recidivism and the Social Reintegration of Offenders. Vienna: UNODC.

UN Security Council. 2014. Resolution 2170. S/RES/2170.

UN Security Council. 2014. Resolution 2178. S/RES/2178.

UN Security Council. 2017. Resolution 2396. S/RES/2396. 
“U Ukrajini puca Srbin na Srbina," Novosti. August 15, 2014. Accessed June 10, 2019. http://www.novosti.rs/vesti/naslovna/drustvo/aktuelno.290.html:505591-U-Ukrajinipuca-Srbin-na-Srbina.

Van Ginkel, Bibi, and Eva Entenmann, eds. 2016. The Foreign Fighters Phenomenon in the European Union: Profiles, Threats \& Policies. The Hague: International Centre for Counter-Terrorism.

Van Waas, Laura. 2016. "Foreign Fighters and the Deprivation of Nationality: National Practices and International Law Implications," In Foreign Fighters under International Law and Beyond, edited by de Guttry, Andrea, Francesca Capone, and Christophe Paulussen, 469-487. The Hague: T.M.C. Asser Press.

Veldhuis, Tinka. 2012. "Designing Rehabilitation and Reintegration Programmes for Violent Extremist Offenders: A Realist Approach.” The Hague: The International Centre for Counter-Terrorism. Accessed June 10, 2019. https://www.icct.nl/download/file/ICCT-Veldhuis-Designing-Rehabilitation-Reintegration-ProgrammesMarch-2012.pdf.

Vidino, Lorenzo et al. 2014. "Foreign Fighters: An Overview of Responses in Eleven Countries," CSS Study. Zurich: Center for Security Studies (CSS) ETH Zurich.Walsh, James. 2007. "Defection and Hierarchy in International Intelligence Sharing." Journal of Public Policy 27 (2): 151-181.

Wæver, Ole. 2004. "Aberystwyth, Paris, Copenhagen: New Schools in Security Theory and the Origins between Core and Periphery." Montreal: ISA Conference.

Williams, Kattie Bo. 2019. “Trump Threatens to 'Release' ISIS Fighters into France, Germany." Defense One, August 21. Accessed January 28, 2020. https://www.defenseone.com/politics/2019/08/trump-threatens-release-isis-fighters-france-germany/159361/.

Xharra, Behar, and Nita Gojani. 2017. Understanding Push and Pull Factors in Kosovo: Primary Interviews with Returned Foreign Fighters and their Families. Pristina: UNDP.

Zivanovic, Maja. 2018a. "Donbass Brothers: How Serbian Fighters Were Deployed in Ukraine." Balkan Insight, December 13. Accessed June 10, 2019. https://balkaninsight.com/2018/12/13/donbass-brothers-how-serbian-fighters-were-deployed-inukraine-12-12-2018/.

Zivanovic, Maja. 2018b. "Serbian Court Jails Seven For Helping Jihadists." Balkan Insight, April 4. Accessed June 10, 2019. https://balkaninsight.com/2018/04/04/ serbian-court-sentenced-seven-for-cooperation-with-isis-04-04-2018/. 